\title{
Changing Trends of NDVI and Their Responses to Climatic Variation in Different Types of Grassland in Inner Mongolia from 1982 to 2011
}

\author{
Jie Yang ${ }^{1,2, \dagger}$, Zhiqiang Wan ${ }^{3,+}$, Suld Borjigin ${ }^{2,4}$, Dong Zhang ${ }^{2,4}$, Yulong Yan ${ }^{2,4}$, Yali Chen ${ }^{2,4}$, \\ Rui Gu ${ }^{5}$ and Qingzhu Gao ${ }^{4,6, *}$ \\ 1 College of Grassland and Environmental Economics, Inner Mongolia University of Finance and Economics, \\ Hohhot 010020, China; jyang@imu.edu.cn \\ 2 School of Ecology and Environment, Inner Mongolia University, Hohhot 010021, China; \\ sue1900@163.com (S.B.); dongdong4590@163.com (D.Z.); 15904881017@163.com (Y.Y.); \\ 13314889391@126.com (Y.C.) \\ 3 College of Geographical Science, Inner Mongolia Normal University, Hohhot 010022, China; \\ wanzhiqiang@imnu.edu.cn \\ 4 Institute of Environment and Sustainable Development in Agriculture, CAAS, Beijing 100081, China \\ 5 College of Grassland, Resources and Environment, Inner Mongolia Agricultural University, Hohhot 010020, \\ China; guruiwudan2008@163.com \\ 6 Key Laboratory for Agro-Environment and Climate Change, Ministry of Agriculture, Beijing 100081, China \\ * Correspondence: gaoqingzhu@caas.cn \\ + Jie Yang and Zhiqiang Wan are co-first authors of the article.
}

Received: 26 April 2019; Accepted: 31 May 2019; Published: 13 June 2019

check for updates

\begin{abstract}
Normalized difference vegetation index (NDVI) is commonly used to indicate vegetation density and condition. NDVI was mostly correlated with climate factors. We analyzed changing trends of NDVI in different types of grassland in Inner Mongolia and the response of NDVI to climatic variation from 1982 to 2011. NDVI of meadow steppe increased significantly in spring while it decreased in other seasons. The annual mean NDVI in typical steppe and desert steppe increased significantly in the last 30a. However, in the greatest area of steppe desert, the NDVI had no significant change in summer, autumn, and the growing season. In meadow steppe, typical steppe, and desert steppe, the area showed a positive correlation of NDVI to temperature as highest in spring compared to other seasons, because warming in spring is beneficial to the plant growth. However, in the greatest area of steppe desert, the correlation of NDVI to temperature was not significant. The NDVI was positively correlated to precipitation in four types of grassland. In the steppe desert, the precipitation had no significant effect on the NDVI due to the poor vegetation cover in this region. The NDVI was not significantly correlated to the precipitation in autumn because of vegetation withering in the season and not need precipitation. Precipitation was a more important factor rather than temperature to NDVI in the region. The response of NDVI to temperature and precipitation in different seasons should be studied in more detail and the effect of other factors on NDVI should be considered in future research.
\end{abstract}

Keywords: temperature; precipitation; NDVI; steppe

\section{Introduction}

NDVI (normalized difference vegetation index) is commonly used for measuring vegetation density and condition from remotely sensed data that show the difference in reflected radiation between visible and near-infrared wavelengths [1], with lower differences indicating sparser vegetation. Climate 
is a main influencing factor for distribution and variation of vegetation [2], but the relationship between NDVI and climate factors was highly complicated [3]. Many studies reported that temperature [4,5] and precipitation $[4,6]$ were closely related with NDVI. However, the constraints of climate on plant growth are dependent on the type of ecosystems across the world $[1,7,8]$. The impacts of climate change on grassland vegetation change vary spatially. Climate change has led to grassland degradation in some regions while also promoting grassland restoration [9]. Warmer and drier climates cause the productivity of North America grassland to decline [10]. Grassland ecosystems in Australia are extremely sensitive to climate change, and global warming has caused a decline in productivity in most grasslands [11]. Climate change has exacerbated grassland degradation in China [12]. Studies have shown that climate change contributes more to grassland degradation than "overgrazing" in Inner Mongolia [13]. At the same time, climate change is one of the main driving factors to grassland desertification in southern and eastern Xinjiang [14].

There exist differences in NDVI trends and the influence of climatic factors on NDVI among different types of grassland in Inner Mongolian Autonomous Region, China [15]. For example, in Hulunbuir, located in the northeast of Inner Mongolia, NDVI of meadow steppe increased significantly from 1982 to 1999, and was positively correlated with the mean temperature [16]. In typical steppe dominated by Leymus chinensis, the influence of temperature on NDVI was greater than precipitation, from 1983 to 1999 [17]. However, in the same time period, NDVI of desert steppe rose slowly with fluctuations [18] and the influence of the precipitation was greater than temperature, which is consistent with the results in the whole Mongolian Plateau [19].

The grassland ecosystems are very sensitive to climate change in Inner Mongolia [20]. For projection, the temperature and precipitation would increase in the future in Inner Mongolia [21]. To date, few studies have focused on the vegetation change in different seasons under climate change conditions in Inner Mongolia. In this study, we want to show (1) the spatiotemporal variations of NDVI in three types of grassland in different seasons, (2) the correlations of NDVI to temperature and precipitation in three types of grassland in different seasons, and (3) examine how different combinations of regional temperature and precipitation drive changes in processes over the same time period.

\section{Materials and Methods}

\subsection{Study Area}

The Inner Mongolia Autonomous Region extends $2400 \mathrm{~km}$ from northeast to southwest and $1700 \mathrm{~km}$ from north to south, covering 1,183,000 $\mathrm{km}^{2}$. The temperate continental monsoon climate was characterized by low rainfall and a large diurnal temperature range. Temperature increased from east to west in the region, and showed four characteristics: winter was long, up to about 200 days; summer was short, generally 90-100 days; temperature had a sudden increase in spring and a sharp fall in autumn; annual range and daily range was large, generally $33-34{ }^{\circ} \mathrm{C}$ and $12-16{ }^{\circ} \mathrm{C}$, respectively.

Precipitation decreases from southeast to northwest, and annual precipitation can reach more than $450 \mathrm{~mm}$ in the east, and only about $100 \mathrm{~mm}$ in the west. Precipitation is concentrated in summer, usually in June to August, which accounts for $60 \%-75 \%$ of the annual; precipitation variability is large. From east to west, the annual evaporation is increasing gradually and is $3-5$ times the annual precipitation in the region.

Grassland covers 788,000 $\mathrm{km}^{2}$ in Inner Mongolia [22]. The types of grassland are transited (from east to west) from meadow steppe to typical steppe, desert steppe, and steppe desert, with similar production potential, similar limiting factors, and the same vegetation subtype in zonal habitats [23].

\subsection{Sources and Data Processing}

\subsubsection{Grassland Types}

A vegetation map covering Inner Mongolia was digitized and validated during field visits for subsequent processing in ArcGIS software [23]. Seven ecological regions in the result of Li [23], 
coniferous forest region in the Greater Khingan Range, deciduous broad-leaved forest region, and desert region were excluded. The four types of grassland were meadow steppe, typical steppe, desert steppe, and steppe desert (Figure 1), according to Li [23].

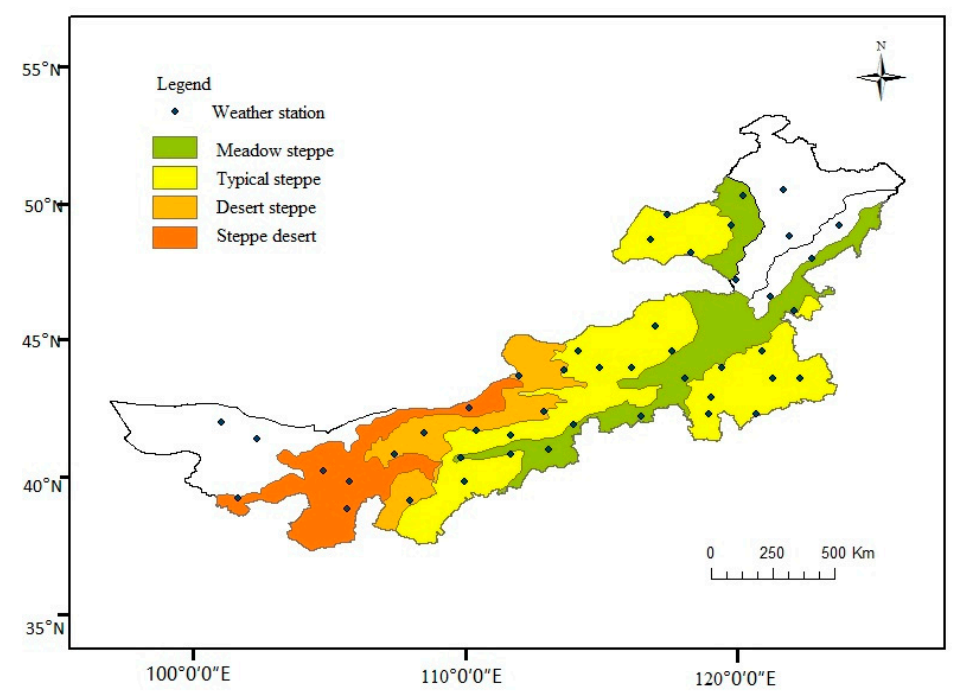

Figure 1. Spatial distribution of vegetation types and location of sampled meteorological stations, Inner Mongolia.

\subsubsection{Meteorological Data}

Meteorological data were obtained from 46 weather stations in Inner Mongolia (Figure 1) those had continuous data from 1982 to 2011. Six stations were included in steppe region, but they were near to the meadow steppe and steppe desert and the temperature and precipitation was similar with the near stations in the meadow steppe and steppe desert region (http://data.cma.cn/). Average monthly temperature and precipitation were calculated by daily data from 1982 to 2011 and which were used to analyze the average seasonal and annual mean values. We calculated average temperature and precipitation in five intra-annual time periods, including spring (March-May), summer (June-August), autumn (September-November), growing season (May-September) [24,25], and the full year in each weather station. We used the inverse distance weighted method and ordinary Kriging method to interpolate average temperature and precipitation for each grid cell in the study area.

\subsubsection{NDVI Maximum Value Composite Procedure}

NDVI was calculated from the NOAA/AVHRR (National Oceanic and Atmospheric Administration/ Advanced Very High Resolution Radiometer, USA) data from 1982 to 2011, which has a spatial resolution of $8 \mathrm{~km}$ and a time interval of ten days, from GIMMS (Global Inventory Monitoring and Modeling Studies). We used the maximum value composite procedure to derive the NDVI for each of these intra-annual time periods in each year from 1982 to 2011. This method involved selecting the highest NDVI for each grid cell from the ten-day interval datasets that fell within each time period and preparing a composite map of these values for each time period. This method reduces the impact of variations in reflectance resulting from cloud cover, atmospheric constituents such as water vapor and aerosols, and solar zenith angles [26].

The maximum of NDVI is calculated from 36 ten day-interval data of each year from 1982 to 2011.

$$
M_{N D V I, i}=\max _{j=1}^{36}\left(I_{N D V I, i j}\right)
$$

$\mathrm{M}_{\mathrm{NDVI}, \mathrm{i}}$ is the maximum of NDVI that vegetation coverage is best in the year, $\mathrm{I}_{\mathrm{NDVI}, \mathrm{ij}}$ is the NDVI in $\mathrm{j}$ ten days in a year. 


\subsubsection{Statistical Analysis}

We analyzed the trend of NDVI from 1982 to 2011 in each grid cell in each time period. We mapped grid cells with a significant increase or decrease $(p<0.05)$ in NDVI in the various time periods, as established by $t$-test [4].

We examined the relationship between NDVI and average temperature and precipitation from 1982 to 2011. For each time period, we calculated spatial correlation coefficients between grassland NDVI and precipitation or temperature using the gridded data. The calculation formula was as follows [19]:

$$
r=\frac{\sum_{i=1}^{n}\left(x_{i}-\bar{x}\right)(y-\bar{y})}{\sqrt{\sum_{i=1}^{n}\left(x_{i}-\bar{x}\right)^{2} \sum_{i=1}^{n}(y-\bar{y})}},
$$

where $\mathrm{n}$ is the annual sequence number, $\mathrm{xi}$ is the NDVI value or climate factor value for a single pixel in i year, $x$ is the annual average of the NDVI or climate factor value, $y_{i}$ is the climatic factor of a certain pixel in a given year, $y$ is the mean value for that climatic factor for all pixels in the given year.

Data were processed with the assistance of the ENVI5.1 software (from Exelis Visual Information Solutions), and the $\mathrm{T}$ test and spatial correlation analysis were calculated through the application of MATLAB software (from MathWorks).

\section{Results}

\subsection{Spatial and Temporal Variation in NDVI}

The trend in NDVI across the 30 years from 1982 to 2011 was different in each grassland type and each time period (Figure 2). There exist high variations in NDVI at meadow steppe and typical steppe in different seasons while no significant changing trends in NDVI at desert steppe and steppe desert (Figure 2).
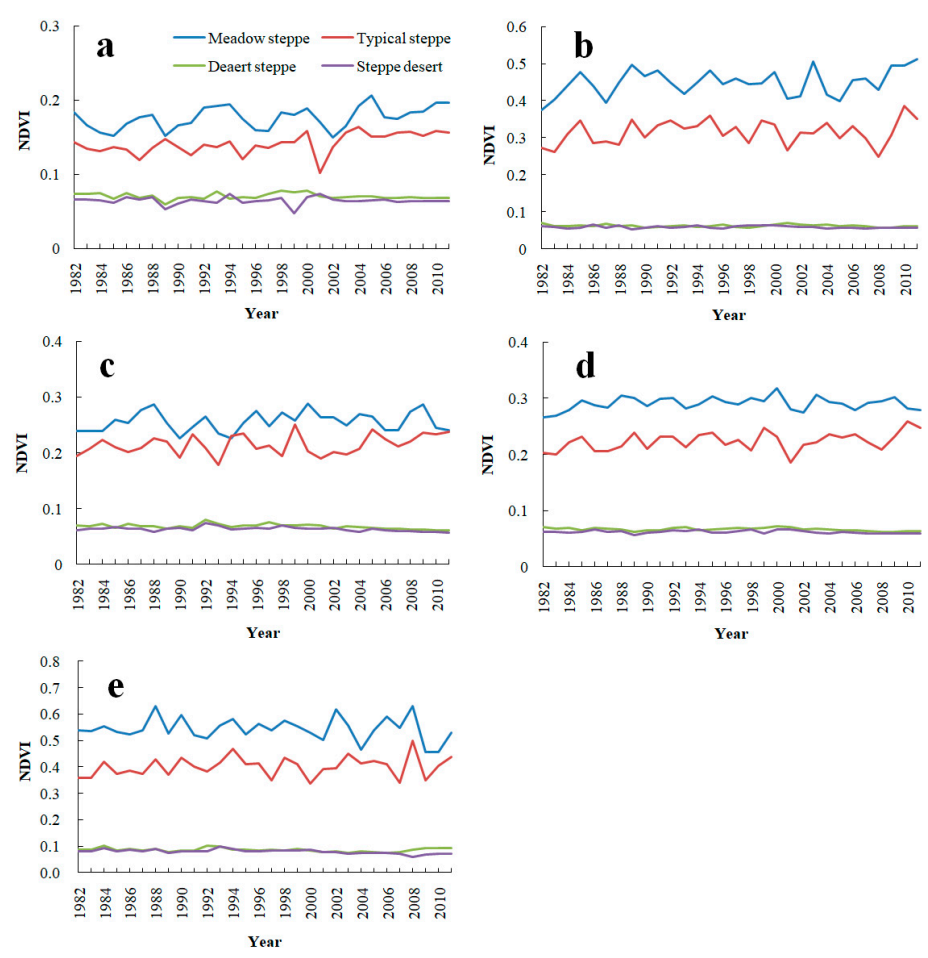

Figure 2. The trends in normalized difference vegetation index (NDVI) of different type steppe in Inner Mongolia from 1982 to 2011 in (a) Spring; (b) Summer; (c) Autumn; (d) growing season; and (e) full year. 
Interannual variation of NDVI for different types of grassland showed a significant spatial variation. At meadow steppe, the ratio of an increasing trend in NDVI in spring was obviously higher than that in other seasons while the decreasing ratio of NDVI was lower in spring than that in other seasons. The increasing ratio of NDVI in typical steppe and desert steppe was higher than the decreasing ratio on five intra-annual time periods. The NDVI was not changed significantly in steppe desert (Table 1).

Table 1. Area proportion of NDVI trends on five intra-annual time periods were shown on different grassland types in Inner Mongolia, from 1982 to 2011.

\begin{tabular}{ccccc}
\hline \multirow{2}{*}{ Steppe Type } & $\begin{array}{c}\text { Intra-Annual } \\
\text { Time Period }\end{array}$ & $\begin{array}{c}\text { Increasing Trend } \\
(p<\mathbf{0 . 0 5})\end{array}$ & $\begin{array}{c}\text { Decreasing Trend } \\
(\boldsymbol{p}<\mathbf{0 . 0 5})\end{array}$ & $\begin{array}{c}\text { No Significant } \\
\text { Trend }\end{array}$ \\
\hline \multirow{5}{*}{ Meadow steppe } & Spring & 20 & 4 & 76 \\
& Summer & 4 & 27 & 69 \\
& Autumn & 7 & 14 & 79 \\
& Growing season & 4 & 28 & 68 \\
& Full year & 4 & 28 & 68 \\
\hline \multirow{5}{*}{ Typical steppe } & Spring & 18 & 13 & 69 \\
& Summer & 21 & 3 & 76 \\
& Autumn & 20 & 10 & 70 \\
& Growing season & 21 & 4 & 75 \\
\cline { 2 - 5 } Desert steppe & Full year & 22 & 4 & 74 \\
& Spring & 30 & 7 & 63 \\
& Summer & 20 & $<1$ & 79 \\
& Autumn & 13 & 2 & 79 \\
& Growing season & 20 & $<1$ & 79 \\
\hline \multirow{5}{*}{ Steppe desert } & Full year & 20 & $<1$ & 85 \\
& Spring & 10 & 5 & 87 \\
& Summer & 4 & 9 & 93 \\
& Autumn & 5 & 2 & 93 \\
& Growing season & 5 & 2 & 93 \\
\hline
\end{tabular}

The NDVI increased significantly with $20 \%$ in the north of meadow steppe, $18 \%$ in central and west of typical steppe, $30 \%$ in northeast and southwest of desert steppe, and $10 \%$ in the west of steppe desert increasing in spring $(p<0.05)$ (Table 1, Figure 3a). The NDVI decreased significantly with $13 \%$ in the east of typical steppe and $7 \%$ in northwest of desert steppe decreasing in spring $(p<0.05)$ (Table 1 , Figure 3a). In summer, the NDVI decreased significantly with $27 \%$ in the east of meadow steppe and $9 \%$ the west of steppe desert decreasing $(p<0.05)$ (Table 1, Figure $3 b)$. In autumn, the NDVI had not changed significantly as $93 \%$ in the steppe desert remained similar $(p>0.05)$ (Table 1, Figure $3 c)$. In the growing season, the changing trend of NDVI was similar to that in summer. However, the NDVI of steppe desert significantly decreased with $9 \%$ in summer while having not changed significantly $93 \%$ in the growth season (Table 1, Figure 3d). Throughout the biggest changing trend of the year, the NDVI of meadow steppe decreased significantly at $28 \%$, with $93 \%$ of steppe desert had no significant change, consistent with changing trend of the NDVI in the growing season (Figure 3, Table 1). 

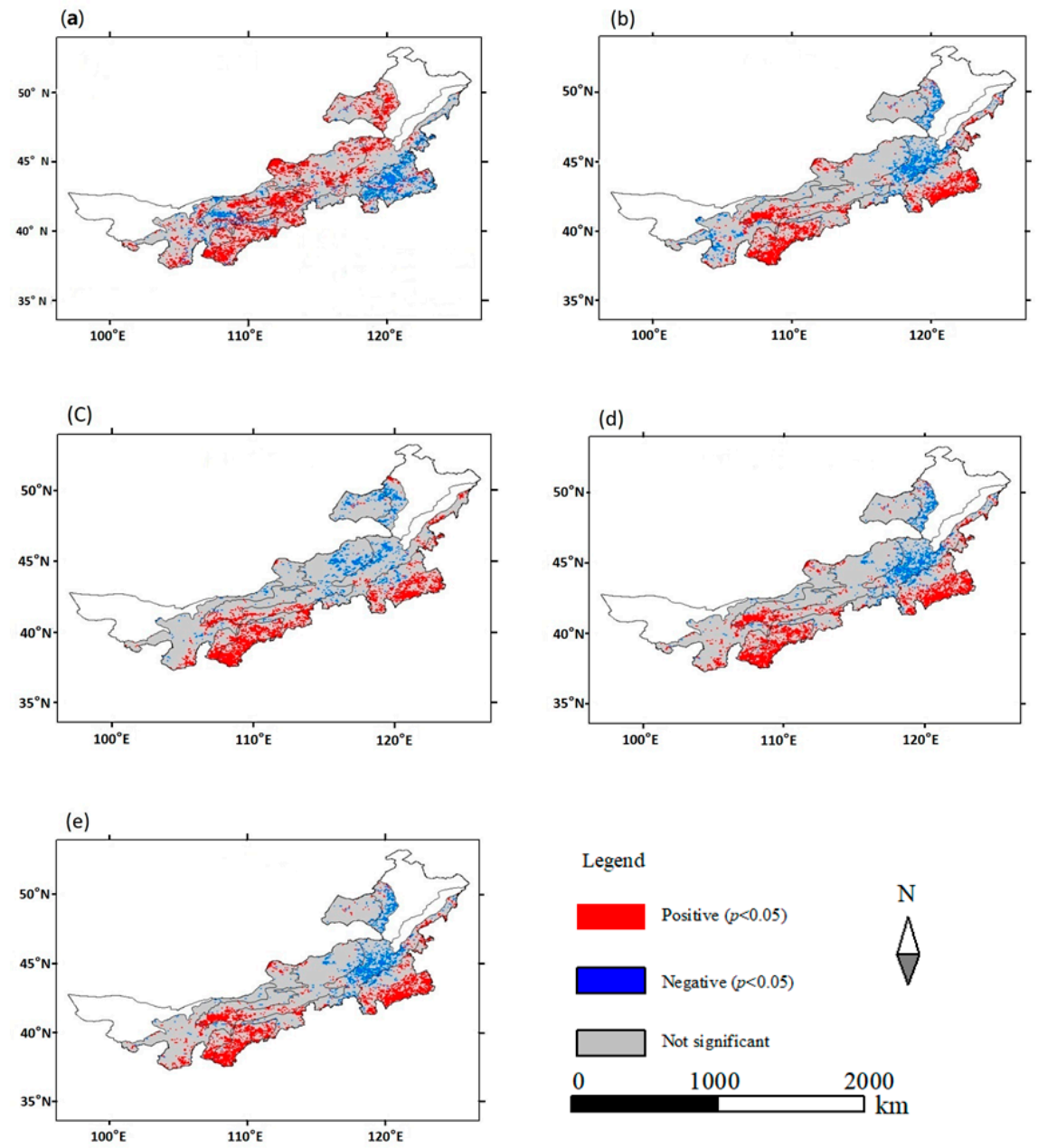

Figure 3. Spatial distribution of increasing and decreasing trends $(p<0.05)$ in NDVI of Inner Mongolia grasslands between 1982 and 2011 in (a) Spring; (b) Summer; (c) Autumn; (d) growing season; and (e) full year.

\subsection{Relationship between NDVI and Temperature}

The correlation of NDVI to temperature was similar in meadow steppe and typical steppe. The ratio of positive correlation was higher in spring than that in other seasons, reached $25 \%$ and $17 \%$, respectively, in meadow steppe and typical steppe. Warming was closely related to the plant growth and vegetation pattern in meadow steppe and typical steppe in spring. The ratio of negative correlation between NDVI and temperature was higher in the growing season and the full year. The NDVI was positively correlated to the temperature in $19 \%$ of the desert steppe in spring while the NDVI was negatively correlated to the temperature in $28 \%$ of the steppe desert in autumn (Table 2).

On the spatial scale, the NDVI was positively correlated to temperature in spring except for the northeast of the typical steppe (Figure 4a). In summer and growing season, the NDVI was negatively correlated to temperature except for the east part of typical steppe and north and east part of desert steppe (Figure $4 \mathrm{~b}, \mathrm{~d}$ ). Annual mean NDVI was not correlated to temperature, especially in desert steppe and steppe desert (Figure 4e). 
Table 2. Area proportion of correlation between NDVI and average temperature on five intra-annual time periods were shown on different grassland types in Inner Mongolia, from 1982 to 2011.

\begin{tabular}{ccccc}
\hline Steppe Type & Intra-Annual Time Period & Positive $(\boldsymbol{p}<\mathbf{0 . 0 5})$ & Negative $(p<\mathbf{0 . 0 5})$ & No Correlation \\
\hline \multirow{4}{*}{ Meadow steppe } & Spring & 25 & $<1$ & 74 \\
& Summer & $<1$ & 23 & 76 \\
& Autumn & 4 & $<1$ & 95 \\
& Growing season & $<1$ & 40 & 59 \\
& Full year & 1 & 7 & 92 \\
\hline \multirow{5}{*}{ Typical steppe } & Spring & 17 & 5 & 78 \\
& Summer & 3 & 13 & 84 \\
& Autumn & 10 & $<1$ & 89 \\
& Growing season & 4 & 18 & 78 \\
& Full year & 6 & $<1$ & 93 \\
\hline \multirow{5}{*}{ Desert steppe } & Spring & 19 & $<1$ & 80 \\
& Summer & 7 & 3 & 90 \\
& Autumn & 8 & $<1$ & 91 \\
& Growing season & 4 & 3 & 93 \\
& Full year & 10 & $<1$ & 89 \\
\hline \multirow{5}{*}{ Steppe desert } & Spring & 2 & $<1$ & 97 \\
& Summer & 2 & 6 & 92 \\
& Autumn & 2 & 28 & 70 \\
& Growing season & 1 & 5 & 94 \\
& Full year & 1 & 3 & 96 \\
\hline
\end{tabular}
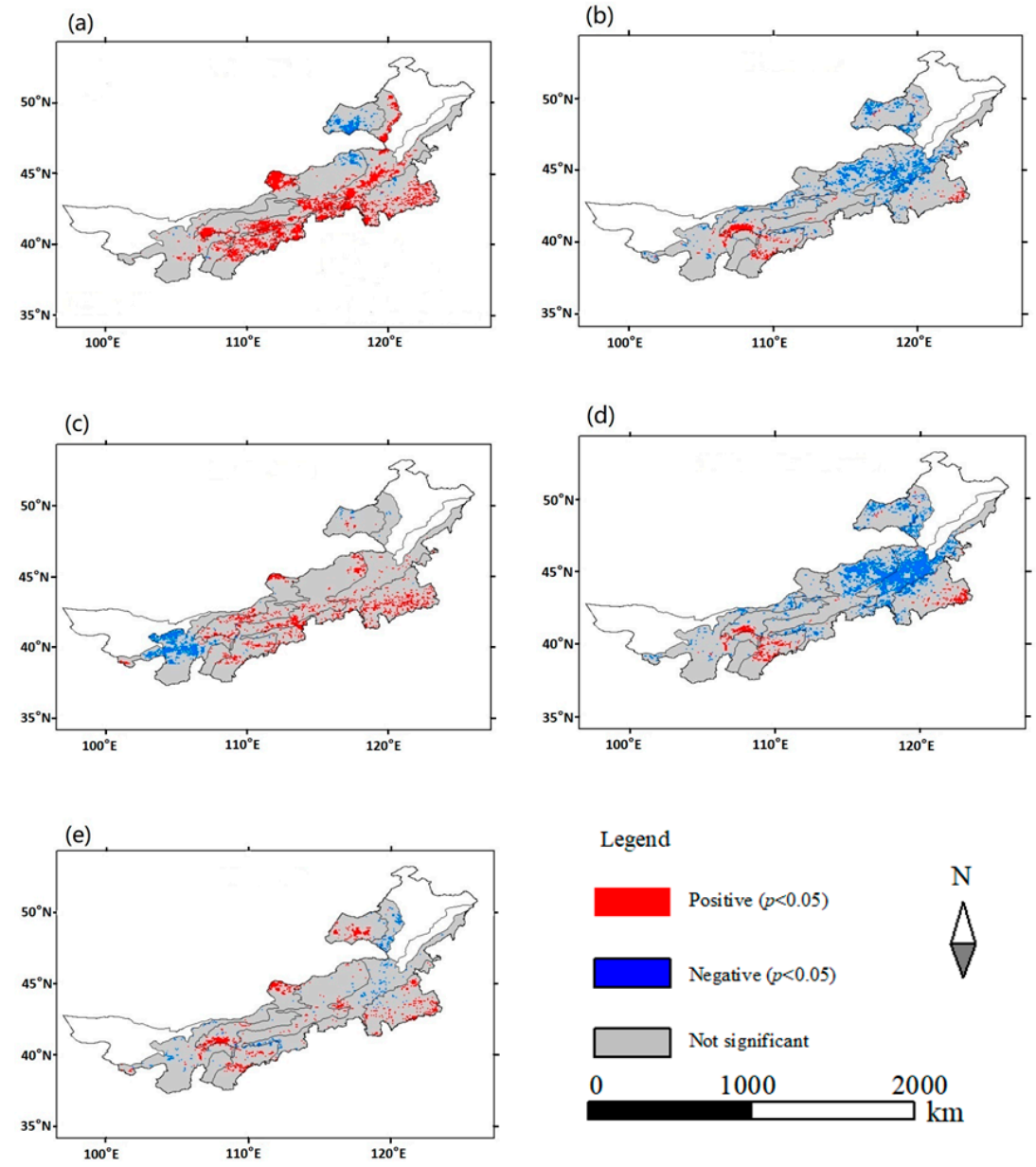

Figure 4. Spatial distribution of significant correlations $(p<0.05)$ between NDVI and average monthly temperature of Inner Mongolia grasslands between 1982 and 2011 in (a) Spring; (b) Summer; (c) Autumn; (d) growing season; and (e) full year. 


\subsection{Relationship between Precipitation and NDVI}

The relationship between NDVI and precipitation was similar in all different types of grassland. The area that showed a positive correlation between NDVI and precipitation was significantly higher than the area that showed a negative correlation in each season except for autumn. The area that showed no significant correlation between NDVI and precipitation was higher than increase and decrease in four types of grassland (Table 3).

Table 3. Area proportion of correlation between NDVI and total precipitation on five intra-annual time periods were shown on different grassland types in Inner Mongolia, from 1982 to 2011.

\begin{tabular}{ccccc}
\hline Steppe Type & Intra-Annual Time Period & Positive $(\boldsymbol{p}<\mathbf{0 . 0 5})$ & Negative $(\boldsymbol{p < 0 . 0 5 )}$ & No Correlation \\
\hline \multirow{4}{*}{ Meadow steppe } & Spring & 18 & 0 & 82 \\
& Summer & 19 & 0 & 81 \\
& Autumn & 1 & 3 & 96 \\
& Growing season & 29 & 0 & 71 \\
& Full year & 21 & 0 & 79 \\
\hline \multirow{5}{*}{ Typical steppe } & Spring & 35 & 1 & 64 \\
& Summer & 43 & 0 & 57 \\
& Autumn & 1 & 3 & 96 \\
& Growing season & 47 & 0 & 53 \\
& Full year & 42 & 0 & 58 \\
\hline \multirow{5}{*}{ Desert steppe } & Spring & 50 & 0 & 50 \\
& Summer & 56 & 0 & 44 \\
& Autumn & 1 & 0 & 99 \\
& Growing season & 57 & 0 & 43 \\
Steppe desert & Full year & 55 & 0 & 45 \\
& Spring & 8 & 0 & 92 \\
& Summer & 35 & 2 & 65 \\
& Autumn & 0 & 0 & 98 \\
& Growing season & 48 & 0 & 52 \\
\hline
\end{tabular}

On the spatial scale, in the spring, the NDVI was positively correlated with precipitation $18 \%$ in meadow steppe, $35 \%$ in meadow steppe, $50 \%$ in desert steppe, and $8 \%$ in steppe desert (Table 1 , Figure 5a). In summer, the NDVI was positively correlated with precipitation $19 \%$ in meadow steppe, $43 \%$ in meadow steppe, $56 \%$ in desert steppe and $35 \%$ in steppe desert (Table 1, Figure 5b). In autumn, the NDVI was not correlated to precipitation $96 \%$ at least in all types of grassland (Table 1, Figure 5c). The regions showing consistent relationships between NDVI and precipitation were consistent in summer, growing season, and the whole year in all types of grassland (Figure $5 b, d, e)$. 

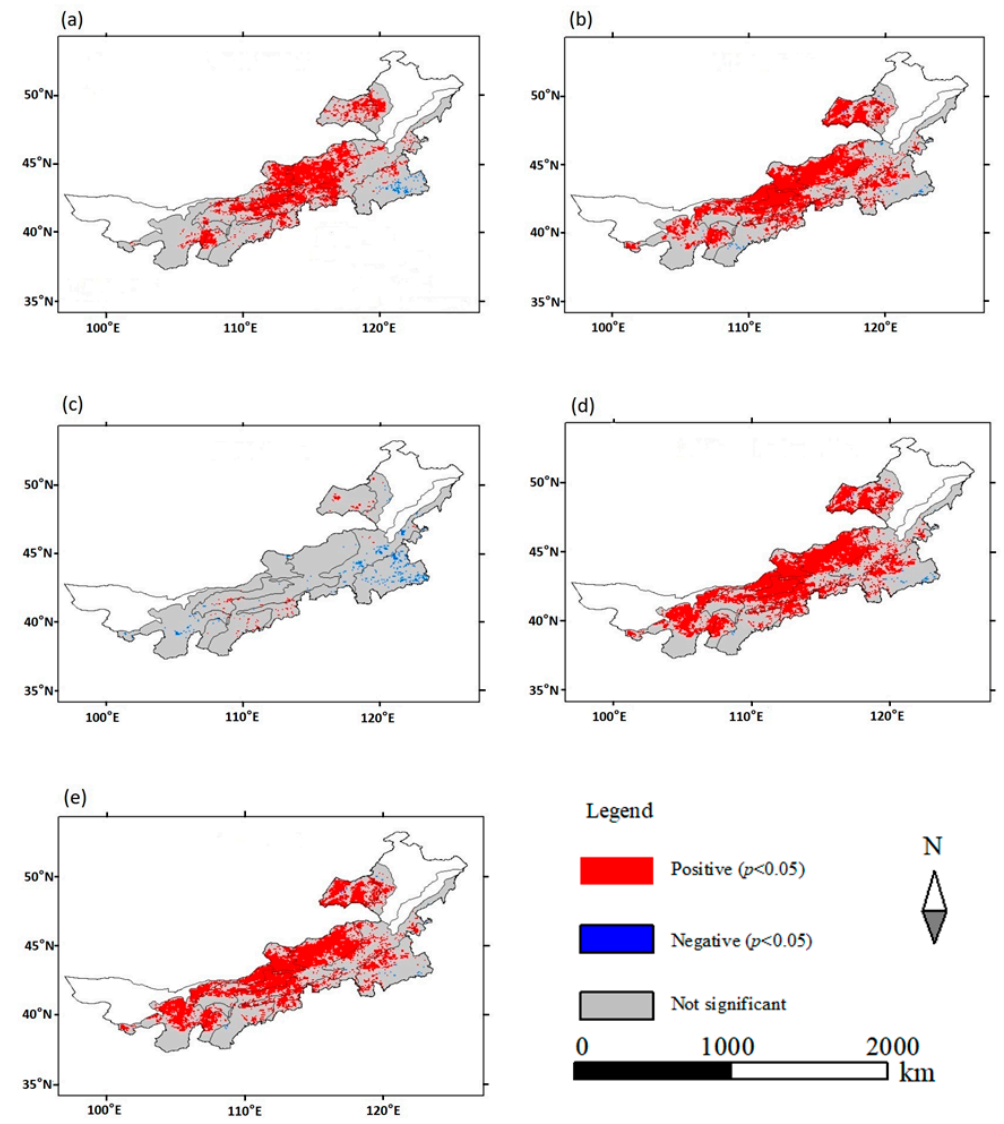

Figure 5. Spatial distribution of significant correlations $(p<0.05)$ between NDVI and monthly precipitation for Inner Mongolia grasslands between 1982 and 2011 in (a) Spring; (b) Summer; (c) Autumn; (d) growing season; and (e) full year.

\section{Discussion}

In our study, the NDVI in meadow steppe and typical steppe were characterized as having high variation but have no significant changing trends except for that in the growing season. The NDVI showed a significant increasing trend in meadow steppe and typical steppe during the growing season from 1982 to 2011. Consistent with our results that NDVI increased in the growing season, Cao showed that NDVI increased since 2007 in the whole Mongolian Plateau [19]. These results may be related to the precipitation change in meadow steppe and typical steppe. The NDVI increased significantly in the southeast and southwest part of Inner Mongolian grasslands in the growing season and full year.

The sensitivity to temperature and precipitation was different among each type of grassland [4]. The NDVI was significantly correlated to precipitation in typical steppe and desert steppe [25]. We found that NDVI was positively correlated with precipitation in four types of grassland. We found that precipitation could affect a larger area of NDVI than temperature. The sensitivity of NDVI to precipitation has previously been shown in arid and semi-arid areas more generally [26-28]. Precipitation is a main influencing factor for the plant growth and vegetation pattern. Precipitation is a limiting factor in desert steppe and typical steppe distributed in the midwest of Inner Mongolia, where the rainfall shortage is unable to meet the demand for water resources. In the meadow steppe regions, temperature is the main factor which influences the NDVI due to high rainfall and adequate water.

Temperature and precipitation were the main driving force of NDVI in spring and the precipitation was the main factor in summer and growing season. Our results are related to Li et al., which showed the relationship between NDVI and climate factors in northern China [24]. In our study, the area showed a significant correlation between NDVI and temperature in spring which was larger than other studies. This may be because the temperature was contributed to the vegetation green up. In this 
region, precipitation was positive to NDVI except in autumn, due to the lower temperature of rainfall at the end of the growing season which will accelerate the vegetation yellowing. The area that NDVI is positive correlated with precipitation was smaller in autumn than in other seasons. It illustrated that the climate factors play a greater role in the greening than that in the withering.

Inner Mongolia has experienced warming and drying over recent decades. Our results indicate that NDVI would increase under future warming and precipitation increasing. However, the factors affect the NDVI were not only temperature and precipitation. Understanding the relationship between vegetation and climate factors is important to introduce a policy for grassland management in Inner Mongolia. Cao et al. also had drawn attention to changes in NDVI that are apparently unrelated to climatic factors, on $40 \%$ of the area, indicating the importance of also accounting spatially for policy, land use and associated changes [25]. Some studies also show that the change of NDVI in Hetao Plain of Inner Mongolia is strongly dependent on irrigation from the Yellow River and does not depend on precipitation [29]. One of the main causes of grassland degradation in Horqin sandy land is extensive reclamation of wastelands. At the same time, overgrazing is the most direct cause of grassland degradation [30]. This paper only distinguishes the process of vegetation cover change in Inner Mongolia Autonomous Region from the impact of climate change on a large scale. To carry out specific vegetation restoration work, further investigation and research on a smaller scale is needed and we should pay more attention to the influence of human activities and other factors in the future.

\section{Conclusions}

The NDVI in meadow steppe increased significantly in spring while decreasing significantly in other seasons from 1982 to 2011. The ratio that NDVI increased significantly in typical steppe was higher than decreased in five seasons. NDVI decreased in spring and increased in other seasons in the north of desert steppe. NDVI increased in spring and decreased in summer in the steppe desert, but did not change significantly in autumn, growing season, and year-round scale in most areas.

The NDVI was positively correlated to temperature in meadow steppe in spring and autumn, and negatively correlated in summer, growing season, and the whole year. NDVI was positively correlated to temperature in eastern region of typical steppe and desert steppe in all seasons. NDVI was negatively correlated to temperature in typical steppe except eastern region in spring, summer, growing season, autumn, and throughout the year. There was a significant positive correlation between NDVI and temperature in spring, with a significant negative correlation in summer, autumn, growing season, and the whole year in steppe desert.

The regional distribution where NDVI had significant correlation to temperature was scattered and largest in spring, while the regional distribution that NDVI had significant correlation to precipitation is more concentrated and smallest in autumn. It showed that the temperature and precipitation are the common driving factors of NDVI change in spring, the temperature is the main driving factor of NDVI change in autumn, and the precipitation is the main driving factor of NDVI change in other seasons.

The response of NDVI to temperature and precipitation in different seasons should be studied in more detail and consider other factors affecting NDVI in future research.

Author Contributions: Conceptualization, J.Y. and Z.W.; methodology, Q.G.; software, S.B.; validation, R.G., Y.Y. and D.Z.; formal analysis, Y.C.; data curation, S.B.; writing-original draft preparation, Z.W.; writing-review and editing, J.Y. and Z.W.; funding acquisition, Q.G.

Funding: The authors gratefully acknowledge financial support from the National Key Research and Development Program of China (2016YFC0500503); National Key R\&D Program of China (2016YFC0502003); National Natural Science Foundation of China (31570484); National Key Project of Scientific and Technical Supporting Program of China (2013BAC09B03); National Forage Industry Projects, China (CARS-34); Inner Mongolia Normal University's Start-up Funding Project of Introducing High-level Talents for Scientific Research (2018YJRC004).

Conflicts of Interest: We make sure that all authors declare no conflict of interest. 


\section{References}

1. Nemani, R.R.; Keeling, C.D.; Hashimoto, H.; Jolly, W.M.; Piper, S.C.; Tucker, C.J. Climate-driven increases in global terrestrial net primary production from 1982 to 1999. Science 2003, 300, 1560-1563. [CrossRef] [PubMed]

2. Woodward, F.I.; McKee, I.F. Vegetation and climate. Environ. Int. 1991, 17, 535-546. [CrossRef]

3. Horion, S.; Cornet, Y.; Erpicum, M.; Tychon, B. Studying interactions between climate variability and vegetation dynamic using a phenology based approach. Int. J. Appl. Earth Obs. Geoinf. 2013, 20, $20-32$. [CrossRef]

4. Piao, S.L.; Mohammat, A.; Fang, J.Y.; Cai, Q.; Feng, J.M. NDVI-based increase in growth of temperate grasslands and its responses to climate changes in China. Glob. Environ. Chang. 2006, 16, 340-348. [CrossRef]

5. Gao, J.G.; Zhang, Y.L.; Liu, L.S.; Wang, Z.F. Climate change as the major driver of alpine grasslands expansion and contraction: A case study in the Mt. Qomolangma (Everest) National Nature Preserve, southern Tibetan Plateau. Quat. Int. 2014, 336, 108-116. [CrossRef]

6. Yang, L.M.; Wylie, B.K.; Tieszen, L.L.; Reed, B.C. An analysis of relationships among climate forcing and time-integrated NDVI of grasslands over the US northern and central Great Plains. Remote Sens. Environ. 1998, 65, 25-37. [CrossRef]

7. Cui, L.L.; Shi, J.; Xiao, F.J.; Fan, W.Y. Variation trends in vegetation NDVI and its correlation with climatic factors in eastern China. Resour. Sci. 2010, 32, 124-131. (In Chinese)

8. Zhao, X.; Tan, K.; Zhao, S.; Fang, J. Changing climate affects vegetation growth in the arid region of the northwestern China. J. Arid Environ. 2011, 75, 946-952. [CrossRef]

9. Yang, Y.; Wang, Z.Q.; Li, J.L.; Gang, C.C.; Zhang, Y.Z.; Zhang, Y.; Odeh, I.; Qi, J.G. Comparative assessment of grassland degradation dynamics in response to climate variation and human activities in china, mongolia, pakistan and uzbekistan from 2000 to 2013. J. Arid Environ. 2010, 135, 164-172. [CrossRef]

10. Polley, H.W.; Briske, D.D.; Morgan, J.A.; Wolter, K.; Bailey, D.W.; Brown, J.R. Climate change and north american rangelands: Trends, projections, and implications. Rangel. Ecol. Manag. 2013, 66, 493-511. [CrossRef]

11. Mckeon, G.M.; Stone, G.S.; Syktus, J.I.; Carter, J.O.; Flood, N.R.; Ahrens, D.G.; Bruget, D.N.; Chilcott, C.R.; Cobon, D.H.; Cowley, R.A.; et al. Climate change impacts on Australia's rangeland livestock carrying capacity: A review of issues. Rangel. J. 2009, 31, 1-29. [CrossRef]

12. Han, J.G.; Zhang, Y.J.; Wang, C.J.; Bai, W.M.; Wang, Y.R.; Han, G.D.; Li, L.H. Rangeland degradation and restoration management in china. Rangel. J. 2008, 30, 233. [CrossRef]

13. Wang, Z.; Deng, X.; Song, W.; Li, Z.; Chen, J. What is the main cause of grassland degradation? A case study of grassland ecosystem service in the middle-south Inner Mongolia. Catena 2017, 150, 100-107. [CrossRef]

14. Zheng, W.; Zhu, J.Z. Analysis of desertification process and driving force factors in grassland ecosystem of Xinjiang. Pratac. Sci. 2012, 29, 1340-1351. (In Chinese)

15. Chuai, X.W.; Huang, X.J.; Wang, W.J.; Bao, G. NDVI, temperature and precipitation changes and their relationships with different vegetation types during 1998-2007 in Inner Mongolia, China. Int. J. Climatol. 2013, 33, 1696-1706. [CrossRef]

16. Ma, Y.L.; Yu, W.H.; Fang, X.Q. Change of grass growth in the Hulunbuir steppe in response to global warming. Arid Land Geogr. 2004, 27, 29-34. (In Chinese)

17. Gu, Z.H.; Chen, J.; Shi, P.J.; Xu, M. Correlation analysis of NDVI difference series and climate variables in Xilingole steppe from 1983 to 1999. Acta Phytoecol. Sin. 2005, 29, 753-765. (In Chinese)

18. Li, X.B.; Chen, Y.H.; Zhang, Y.X.; Fan, Y.D.; Zhou, T.; Xie, F. Impact of Climate Change on Desert in Northern China. Adv. Earth Sci. 2002, 2, 254-261. (In Chinese)

19. Cao, X.J.; Gao, Q.Z.; Ganjurjav, H.; Liang, Y.; Li, W.H.; Hu, G.Z. Influence of climatic factors on variation in the Normalised Difference Vegetation Index in Mongolian Plateau grasslands. Rangel. J. 2017, 40.

20. Yang, T.; Li, P.; Wu, X.; Hou, X.; Liu, P.; Yao, G. Assessment of vulnerability to climate change in the Inner Mongolia steppe at a county scale from 1980 to 2009. Rangel. J. 2014, 36, 545-555. [CrossRef]

21. IPCC. Summary for Policymakers. In Climate Change 2013: The Physical Science Basis. Contribution of Working Group I to the Fifth Assessment Report of the Intergovernmental Panel on Climate Change; Stocker, T.F., Qin, D., Plattner, G.-K., Tignor, M., Allen, S.K., Boschung, J., Nauels, A., Xia, Y., Bex, V., Midgley, P.M., Eds.; Cambridge University Press: Cambridge, UK; New York, NY, USA, 2013. 
22. Animal Husbandry Department, Ministry of Agriculture of the People's Republic of China. Monitoring Report of Grassland in China; Animal Husbandry Department, Ministry of Agriculture of the People's Republic of China: Beijing, China, 2014. (In Chinese)

23. Li, B.; Yong, S.P.; Zeng, S.D.; Cui, H.T. Regionalization map of the Inner Mongolia Autonomous region. Acta Phytoecol. Geobot. Sin. 1990, 14, 55-62. (In Chinese)

24. Zhang, C.Q.; Chi, Y. Simulation of growth dynamics of four plants in the typical steppe of Inner Mongolia in growing season. Acta Ecol. Sin. 2007, 27, 3618-3629.

25. Zhang, Q.Y.; Wu, S.H.; Zhao, D.S.; Dai, E.F. Responses of growing season vegetation changes to climatic factors in Inner Mongolia grassland. J. Nat. Resour. 2013, 28, 754-764. (In Chinese)

26. Guo, L.; Wu, S.; Zhao, D.; Yin, Y.; Leng, G.; Zhang, Q. NDVI based vegetation change in Inner Mongolia from 1982 to 2006 and its relationship to climate at the biome scale. Adv. Meteorol. 2014. [CrossRef]

27. Di, L.; Rundquist, D.C.; Han, L. Modelling relationships 45between NDVI and precipitation during vegetative growth cycles. Int. J. Remote Sens. 1994, 2121-2136. [CrossRef]

28. Gessner, U.; Naeimi, V.; Klein, I.; Kuenzer, C.; Klein, D.; Dech, S. The relationship between precipitation anomalies and satellite-derived vegetation activity in Central Asia. Glob. Planet. Chang. 2013, 110, $74-87$. [CrossRef]

29. Xin, Z.B.; Xu, J.X.; Zheng, W. Spatiotemporal variations of vegetation cover on the chinese loess plateau (1981-2006): Impacts of climate changes and human activities. Sci. China Ser. D Earth Sci. 2008, 51, 67-78. (In Chinese) [CrossRef]

30. Jiang, D.M.; Liu, Z.M.; Kou, Z.W.; Alamusa, M.S.; Li, R.P. Ecological environment and its sustainable management of horqin steppe-A report on the survey of horqin sandy land. Chin. J. Ecol. 2004, 23, 179-185. (In Chinese)

(C) 2019 by the authors. Licensee MDPI, Basel, Switzerland. This article is an open access article distributed under the terms and conditions of the Creative Commons Attribution (CC BY) license (http://creativecommons.org/licenses/by/4.0/). 